\title{
Racial Disparities in Pre-tax Wages and Salaries in Largest Metropolitan Areas in the United States
}

http://doi.org/10.21272/bel.5(3).61-68.2021

Achintya Ray, ORCID: https://orcid.org/0000-0003-4269-0268

$\mathrm{PhD}$ in Economics, Professor of Economics, Tennessee State University, Nashville, TN, USA

\section{Abstract}

The article deals with racial disparities in the distribution of pre-tax wages and salaries for employed individuals in the USA between the ages of 18-65. This study is done for the ten largest metropolitan areas of the USA using the 2019 American Community Survey data. The metropolitan areas included in the study are Atlanta-Sandy Springs-Roswell, Chicago-Naperville-Elgin, Dallas-Fort Worth-Arlington, Houston-The Woodlands-Sugar Land, Los Angeles-Long Beach-Anaheim, Miami-Fort Lauderdale-West Palm Beach, New York-Newark-Jersey City, Philadelphia-Camden-Wilmington, San Francisco-Oakland-Hayward, and Washington-Arlington-Alexandria. Employing well over a quarter of the total employed labour force in the USA, these ten metropolitan areas are also some of the largest industrial worlds. Average pre-tax wages and salaries, the standard deviation of the mean and Gini coefficient by major racial categories are presented for each of these ten metropolitan areas. For each metropolitan area, black employed individuals earned less in pre-tax wages and salaries than white employed individuals. The Gini coefficient of black pre-tax wages and wages is also found to be smaller for each of the metropolitan areas compared to the white counterparts. It suggests a much tighter distribution in pre-tax wages and salaries for blacks compared to whites. Furthermore, employed workers from other races earned less in pre-tax wages and salaries than their white counterparts for each major metro. Except for Los Angeles-Long Beach-Anaheim metropolitan area, black employed workers also earned less pre-tax wages and salaries than members of the other races. The Gini coefficients of pre-tax wages and salaries for various metropolitan areas for different races are found to be broadly comparable and often larger than that of the whites. Together, these results point to the fact that the pre-tax wages and salaries of black workers are lower compared to both whites and other races and more tightly distributed. Lastly, the relative inequality between whites and blacks and others and blacks often point to the relatively broader dispersion in the later group compared to the former.

Keywords: Racial Disparities, Income Distribution, Gini Coefficient, Urban Income Distribution, American Community Survey.

JEL Classification: D31, E24, O15, R23.

Cite as: Ray, A. (2021). Racial Disparities in Pre-tax Wages and Salaries in Largest Metropolitan Areas in the United States. Business Ethics and Leadership, 5(3), 61-68. http://doi.org/10.21272/bel.5(3).61-68.2021.

Received: 1 July $2021 \quad$ Accepted: 05 September $2021 \quad$ Published: 13 September 2021

Copyright: (C) 2021 by the author. Licensee Sumy State University, Ukraine. This article is an open access article distributed under the terms and conditions of the Creative Commons Attribution (CC BY) license (https://creativecommons.org/licenses/by/4.0/).

\section{Introduction}

The second half of the 20th century and the first two decades of the 21 st century have seen significant increases in income inequality. This phenomenon has attracted wide-ranging discussions in both press and academia (Acemoglu \& Autor, 2011; Arrow, 1998; Autor, Katz, \& Kearney, 2008; Bertrand \& Mullainathan, 2004; David \& Dorn, 2013; Glaeser \& Resseger, 2010; Heckman, 1998). Rapidly increasing income inequalities are often blamed for increasing political unrest and boosts demand for stronger re-distributive economic policies in many parts of the world. The roles played by race in income inequality, wealth disparities, disparities in skill formation, and various other socioeconomic phenomena have also attracted considerable academic attention in recent times (Chetty, Hendren, Jones, \& Porter, 2020; Collins-dodd, Gordon, \& Smart, 2004; David \& Dorn, 2013; Delgado \& Stefancic, 2017).

Incomes may be derived from many different sources like wages and salaries, asset income, inheritance, government transfers, etc. Several sources of income, like asset income, inheritance, government transfers, etc., may not be affected by an individual's skill, education, and occupational status and may not have a strong relationship with the labor market conditions. To ensure that the source of income is most closely tied to one's 
skills, education, etc. This paper focuses on pre-tax wages and salaries. This source of income is expected to be most closely related to the labour market opportunities and impediments faced by an individual. The role of skill premium as one of the key drivers of inequality in the USA has been extensively studied in many influential academic papers (Juhn, Murphy, \& Pierce, 1993; Koeniger, Leonardi, \& Nunziata, 2007; Lemieux, MacLeod, \& Parent, 2009). The choice of pre-tax wages and salaries to analyze the income inequality and the methods adopted in this paper is most closely related to (Ray, 2021).

The metropolitan areas included in the study are Atlanta-Sandy Springs-Roswell, Chicago-Naperville-Elgin, Dallas-Fort Worth-Arlington, Houston-The Woodlands-Sugar Land, Los Angeles-Long Beach-Anaheim, Miami-Fort Lauderdale-West Palm Beach, New York-Newark-Jersey City, Philadelphia-CamdenWilmington, San Francisco-Oakland-Hayward, and Washington-Arlington-Alexandria. Together, these ten metropolitan areas represent over a quarter of the total employed labor force in the USA. These large metropolitan areas are known for their special roles in the national economy. In the west coast, San Francisco area is the home to Silicon Valley and a major destination of tech-related employment globally. On the east coast, New York is globally known for its financial industry. In the Midwest regions, Chicago has one of the highest concentrations of commodity trading in the world. In the Southeast region of the country, Miami is a major tourist destination. The nation's capital, Washington, D.C., is the major hub of government and international economic policymaking. It is also the seat of major international organizations like the IMF and the World Bank. By analyzing the inequalities in pre-tax wage and salaries in these large metropolitan areas, we can gain a very granular understanding of the inequalities in the overall American labor market. It is especially true given the vast cross-section of industries that these cities cover between them and the close relationship these cities maintain with the rest of the world, thereby connecting the American skilled labour market to various channels of international trade (Moretti, 2012, 2013; Ray, 2021).

This paper finds significant racial disparities in income from pre-tax wages and salaries for employed individuals in these major metropolitan areas. For each metropolitan area, black employed individuals earned less in pre-tax wages and salaries than white employed individuals. The Gini coefficient of black pre-tax wages and wages is also found to be smaller for each of the metropolitan areas compared to the white counterparts. It suggests a much tighter distribution in pre-tax wages and salaries for blacks compared to whites. Furthermore, employed workers from other races earned less in pre-tax wages and salaries than their white counterparts for each major metro. Except for Los Angeles-Long Beach-Anaheim metropolitan area, black employed workers also earned less pre-tax wages and salaries than members of the other races. The Gini coefficients of pre-tax salaries and salaries for various metropolitan areas for other races are found to be largely comparable and often larger than that of the whites. Together these results point to the fact that the pre-tax wages and salaries of the black workers are not only lower compared to both whites and other races but also more tightly distributed.

The results found in this study largely corroborate the endemic racial disparities in the American labour market (Altonji \& Blank, 1999; Bertrand \& Mullainathan, 2004; Blau \& Ferber, 1987; Chetty et al., 2020; Delgado \& Stefancic, 2017; Freeman \& Katz, 1994; Heckman, 1998; Krueger, 1963; Lang \& Lehmann, 2012). This retrospective study based on cross-section data does not claim to provide any definitive causal mechanism through which these disparities are created. In other studies, the magnitude of racial disparities has been attenuated or muted after various causal pathways are accounted for (Angrist \& Krueger, 1999; Boeri \& Van Ours, 2013; Borjas, 1999; Brown, 2011; Fortin, N., Lemieux, \& Firpo, 2011; Heckman, 1998; Lang \& Lehmann, 2012; Lang \& Manove, 2011).

\section{Literature Review}

Inequalities in pre-tax wages and salaries may be expected if workers differ in their core abilities and more productive workers are compensated more than the low productivity workers. In that simple, straightforward world, inequalities in pre-tax wages and salaries will be a simple function of the abilities and may be easily predictable, especially if the skill levels can be observed inexpensively (Angrist \& Krueger, 1999; Heckman, 1998). But information asymmetry can considerably complicate matters for the worse. In the presence of high search costs, the employers may be constrained to keep their overall costs low by hiring a mix of high and low productivity workers while learning about their productivity differences by observing them on the job (Becker, 2010; Neumark, 2018; Rueda \& Pontusson, 2000). This simple view posits that income inequalities may arise even in a world that is characterized by no discrimination, animus, or bias (Bisin \& Gottardi, 2006; Guerrieri, Shimer, \& Wright, 2010; Levine, 1991; Ma, 1991). 
When the true abilities of the workers are not easily observed, then wage inequalities can get affected by the easily observable characteristics like gender, race, membership of social networks, etc. even when no clear animus is present (Becker, 2010; Bertrand \& Mullainathan, 2004; Boeri \& Van Ours, 2013; Brown, 2011; Harrison \& List, 2004; Heckman, 1998; Neumark, 2018; Rueda \& Pontusson, 2000). However, if the observable characteristics are deliberately used to perpetuate animus against a certain section of the society, then the income inequalities may get exacerbated by those active acts of discrimination beyond the naïve differences predicted by the statistical discrimination (Becker, 2010; Bertrand \& Mullainathan, 2004; Bisin \& Gottardi, 2006; Blau \& Ferber, 1987; Phelps, 1972).

The precise drivers of observable income inequalities are often hard to characterize. The existence of skill dispersion and technological advancement can drive income inequalities even in a perfect information framework. Furthermore, the returns to various levels of skills can be reasonably expected to vary and evolve along separate paths as the technology evolves over time (Beyer, Rojas, \& Vergara, 1999; Calvo-Armengol \& Jackson, 2004; Card, 2001; Croson \& Gneezy, 2009; David \& Dorn, 2013; Freeman \& Katz, 1994; Heckman, 1998). Experimental studies often substantively push the frontiers by being able to precisely control the covariates that may contribute to income disparities while holding for various known contributors (Bertrand \& Mullainathan, 2004; Boeri \& Van Ours, 2013; Brown, 2011; Harrison \& List, 2004; Heckman, 1998; Huang, Fowler, \& Baskerville, 2016; Jones \& Kim, 2018; Nance \& Madsen, 2014; Pager \& Shepherd, 2008; Song, Price, Guvenen, Bloom, \& Von Wachter, 2019).

The dispersion in skill levels, educational attainment, socioeconomic disparities, income inequalities may be driven by a host of other factors like the urban agglomerations, exposure to and linkages with international trade channels, and institutionalism. Each of those drivers has attracted widespread attention in the literature too (Arrow, 1998; Blau \& Kahn, 1996; Delgado \& Stefancic, 2017; Fortin, N.M. \& Lemieux, 1997; Freeman \& Katz, 1994; Glaeser \& Resseger, 2010; Hammond \& Streeter, 1994; Heckman, 1998). This paper extends the work of income inequalities in major American metropolitan areas (Ray, 2021). The specific focus of this paper is on the racial disparities in pre-tax wages and salaries for employed individuals in those metropolitan cities both in terms of the mean and for the Gini coefficient.

\section{Methodology and Research Methods}

Data for this paper is collected from the American Community Survey (ACS) for the year 2019. Harmonized data is carefully selected and extracted from IPUMS USA. ACS is the chief source of national demographic, employment, and socioeconomic data between decennial census years. ACS is also conducted annually by the US Census Bureau. Wide-ranging studies use the ACS that look at migration, income, wages, demographic variables, educational attainment for the country, and various regions of America (Ruggles et al., 2021). This study is restricted to the ten largest metropolitan areas in America. The metropolitan areas capture the place of work for the individuals and not necessarily the place of residence. Individuals often reside outside of the metropolitan areas they work in. However, pre-tax wages and salaries for employed individuals are determined by the metropolitan areas where the employing businesses are located and not by the residence by the individuals. Individuals often choose the residence based on its cost of living, proximity to family members, quality of schools, etc. While many individuals live and work in the same metropolitan area, many others do not.

The following metropolitan areas are included in the study:

1. Atlanta-Sandy Springs-Roswell, GA

2. Chicago-Naperville-Elgin, IL-IN-WI

3. Dallas-Fort Worth-Arlington, TX

4. Houston-The Woodlands-Sugar Land, TX

5. Los Angeles-Long Beach-Anaheim, CA

6. Miami-Fort Lauderdale-West Palm Beach, FL

7. New York-Newark-Jersey City, NY-NJ-PA

8. Philadelphia-Camden-Wilmington, PA-NJ-DE

9. San Francisco-Oakland-Hayward, CA

10.Washington-Arlington-Alexandria, DC-VA

Some metropolitan areas are entirely contained in a single state in that their boundaries do not cross the state lines. In other cases, metropolitan areas may be spread over several states in that the boundaries of the metropolitan areas cross state boundaries. For example, the boundaries of the Atlanta-Sandy Springs-Roswell metropolitan area are entirely inside the state of Georgia. But the boundaries of Philadelphia-Camden- 
Wilmington metropolitan area cross several state lines for numerous north-eastern states, including Pennsylvania, New Jersey, and Delaware. Similarly, New York-Newark-Jersey City metropolitan area is also spread over three neighboring states: New York, New Jersey, and Pennsylvania. On the West coast, San Francisco-Oakland-Hayward is entirely contained inside the state of California. In the lest above, the state(s) in which the metropolitan areas are located are also provided alongside the names of the metropolitan areas.

Employed individuals between the ages of 18 and 65 are included in the study. For income, total pre-tax wage and salary income received as an employee over the preceding 12 months is the appropriate variable. The total pre-tax wage and salary incomes are measured in 2019 US Dollars. This compensation includes wages, salaries, commissions, cash bonuses, tips, and other money incomes while working for an employer. It may be noted that the payments-in-kind or reimbursements for business expenses are not included in the pre-tax wage and salary incomes. Observations with missing or non-positive pre-tax wages and salaries are excluded from the statistical analysis and summary measures. Observations with missing (employment-related) metropolitan areas identifier are also excluded from this study. The pre-tax wages and salary incomes are Winsorized to maintain the middle $95 \%$ of the data to ensure that outlier values do not bias the results. It is achieved by removing the lowest $2.5 \%$ and highest $2.5 \%$ of the values. These special truncations are performed on a metroby-metro basis. It is specifically done to allow for individual metro level compatibility. Restricting the Winsorization to the individual metro level ensures that inter-metro differences do not bias the values of any particular metropolitan region. The samples are weighted by the appropriate census recommended sample weights to attain population level figures.

The pre-tax wage and salary incomes are used to calculate the mean for each of the races along with the standard deviation of the mean and the Gini coefficient for each of the metropolitan areas. Gini coefficient is used as the measure of income inequality in this paper. Gini coefficient is the main measure of inequality used in this paper. It may be mathematically calculated as half of the relative mean absolute difference based on the Lorenz curve. We may also define the mean absolute difference as the average absolute difference of all pairs of pre-tax wage and salary incomes of the populations for each of the metropolitan areas. Furthermore, the relative mean absolute difference is defined as the mean absolute difference divided by the pre-tax wage and salary income average. This adjustment is done to normalize for scale and this rescaling ensures that we can compare the Gini coefficient from different metro areas (Lambert \& Aronson, 1993; Milanovic, 1997; Yitzhaki, 1979).

The mathematical derivation of the Gini coefficient may be presented in the following manner. Assuming that $x_{i}$ is the pre-tax wage and salary income of person $i$, the Gini coefficient may be formally defined for discrete distribution as

$$
G=\frac{\sum_{i=1}^{n} \sum_{j=1}^{n}\left|x_{i}-x_{j}\right|}{2 \sum_{i=1}^{n} \sum_{j=1}^{n} x_{j}}=\frac{\sum_{i=1}^{n} \sum_{j=1}^{n}\left|x_{i}-x_{j}\right|}{2 n \sum_{j=1}^{n} x_{j}}=\frac{\sum_{i=1}^{n} \sum_{j=1}^{n}\left|x_{i}-x_{j}\right|}{2 n^{2} \bar{x}}
$$

However, pre-tax wage and salaries may also be represented as a continuous variable. For a continuous distribution, the Gini coefficient may be conveniently expressed as

$$
G=\frac{1}{2 \mu} \int_{-\infty}^{\infty} \int_{-\infty}^{\infty} p(x) p(y)|x-y| d x d y
$$

where $\mu=\int_{-\infty}^{\infty} x p(x) d x$ or, the mean of the underlying distribution.

Please note that the Gini coefficient $(\mathrm{G})$ is $0 \leq G \leq 1$. Also, $\mathrm{G}=0$ represents absence of any inequality or perfect equality and $\mathrm{G}=1$ represents extreme inequality or complete lack of equality. In the later case, the entire pre-tax wage and salary essentially belongs to a single individual. Rising income inequality is represented through an increasing Gini coefficient. For example, a metropolitan area with $G=0.5$ is more unequal than another metropolitan area with $G=0.4$.

\section{Results}

The number of workers by race and the mean pre-tax wage and salaries along with their standard errors are presented for each of the metros in Table 1. Each of the metropolitan areas had several millions of workers but the racial composition of the workforce differs from one metropolitan area to another. The highest number of white employed individuals are found in New York-Newark-Jersey City, NY-NJ-P followed by Los AngelesLong Beach-Anaheim, CA and Chicago-Naperville-Elgin, IL-IN-WI. The smallest number of white employees are in San Francisco-Oakland-Hayward, CA. The highest number of black employed individuals are found in 
New York-Newark-Jersey City, NY-NJ-PA followed by Atlanta-Sandy Springs- Roswell, GA and Washington-Arlington-Alexandria, DC-VA. The highest number of employed individuals from other races is found in Los Angeles-Long Beach-Anaheim, CA followed by New York-Newark-Jersey City, NY-NJ-PA and San Francisco-Oakland-Hayward, CA.

Besides the absolute numbers, the racial composition also varies widely between the metropolitan areas. For example, in the Atlanta-Sandy Springs- Roswell, GA metropolitan area, there are 1.54 white workers for every black worker, but in Chicago-Naperville-Elgin, IL-IN metropolitan area, there are 4.78 white workers for every black worker. The exact ratio is 8.64 in Los Angeles-Long Beach-Anaheim, CA metropolitan area. The percentage of other workers to black workers also differed considerably across the metropolitan areas. For example, 2.83 times more black workers than workers from other races in Atlanta-Sandy Springs- Roswell, GA. But in San Francisco-Oakland-Hayward, CA metropolitan area, there are 6.3 workers from different races for every black worker. The same is approximately true for the Los Angeles-Long Beach-Anaheim, CA.

Table 1. Number of Workers and Basic Summary Statistics for Pre-tax Wages and Salaries by Major Racial Categories

\begin{tabular}{|c|c|c|c|c|c|c|}
\hline \multirow[t]{2}{*}{ Metropolitan Area } & \multicolumn{2}{|c|}{ White } & \multicolumn{2}{|c|}{ Black } & \multicolumn{2}{|c|}{ Others } \\
\hline & $\begin{array}{c}\text { Weighted } \\
\text { Sample } \\
\text { Size } \\
\text { (Population } \\
\text { Estimate) } \\
\end{array}$ & $\begin{array}{l}\text { Mean Pre-tax } \\
\text { wages and } \\
\text { salaries }\end{array}$ & $\begin{array}{c}\text { Weighted } \\
\text { Sample Size } \\
\text { (Population } \\
\text { Estimate) }\end{array}$ & $\begin{array}{c}\text { Mean Pre-tax } \\
\text { wages and } \\
\text { salaries }\end{array}$ & $\begin{array}{c}\text { Weighted } \\
\text { Sample Size } \\
\text { (Population } \\
\text { Estimate) }\end{array}$ & $\begin{array}{c}\text { Mean Pre- } \\
\text { tax wages } \\
\text { and salaries }\end{array}$ \\
\hline $\begin{array}{c}\text { Atlanta-Sandy Springs- } \\
\text { Roswell, GA }\end{array}$ & $1,454,984$ & $\begin{array}{c}65,883.69 \\
(46.72)\end{array}$ & 945,493 & $\begin{array}{c}44,136.85 \\
(36.51)\end{array}$ & 333,352 & $\begin{array}{c}52,980.32 \\
(86.51)\end{array}$ \\
\hline $\begin{array}{l}\text { Chicago-Naperville- } \\
\text { Elgin, IL-IN-WI }\end{array}$ & $2,935,974$ & $\begin{array}{l}65,252.21 \\
(33.12)\end{array}$ & 614,081 & $\begin{array}{c}43,268.35 \\
(47.78)\end{array}$ & 787,581 & $\begin{array}{c}52,431.63 \\
(55.59)\end{array}$ \\
\hline $\begin{array}{l}\text { Dallas-Fort Worth- } \\
\text { Arlington, TX }\end{array}$ & $2,303,536$ & $\begin{array}{c}59,285.95 \\
(34.29)\end{array}$ & 569,798 & $\begin{array}{c}44,537.86 \\
(46.83)\end{array}$ & 556,268 & $\begin{array}{c}53,079.14 \\
(63.31) \\
\end{array}$ \\
\hline $\begin{array}{l}\text { Houston-The Woodlands- } \\
\text { Sugar Land, TX }\end{array}$ & $1,922,285$ & $\begin{array}{l}60,800.67 \\
(39.72)\end{array}$ & 524,404 & $\begin{array}{l}44,697.75 \\
(51.43)\end{array}$ & 562,201 & $\begin{array}{c}52,856.21 \\
(66.72)\end{array}$ \\
\hline $\begin{array}{c}\text { Los Angeles-Long Beach- } \\
\text { Anaheim, CA }\end{array}$ & $3,228,795$ & $\begin{array}{c}61,179.74 \\
(30.61)\end{array}$ & 373,616 & $\begin{array}{c}50,739.95 \\
(68.95)\end{array}$ & $2,357,520$ & $\begin{array}{c}50,185.28 \\
(29.13)\end{array}$ \\
\hline $\begin{array}{l}\text { Miami-Fort Lauderdale- } \\
\text { West Palm Beach, FL }\end{array}$ & $1,910,494$ & $\begin{array}{c}51,443.82 \\
(33.69) \\
\end{array}$ & 575,566 & $\begin{array}{c}36,257.57 \\
(40.29) \\
\end{array}$ & 239,828 & $\begin{array}{c}44,992.01 \\
(86.50) \\
\end{array}$ \\
\hline $\begin{array}{c}\text { New York-Newark-Jersey } \\
\text { City, NY-NJ-PA }\end{array}$ & $5,256,550$ & $\begin{array}{c}79,562.92 \\
(32.06)\end{array}$ & $1,499,095$ & $\begin{array}{c}50,607.35 \\
(35.85)\end{array}$ & $2,229,838$ & $\begin{array}{c}60,272.23 \\
(41.04)\end{array}$ \\
\hline $\begin{array}{l}\text { Philadelphia-Camden- } \\
\text { Wilmington, PA-NJ-DE }\end{array}$ & $1,816,876$ & $\begin{array}{c}64,930.83 \\
(39.84)\end{array}$ & 491,001 & $\begin{array}{c}43,721.82 \\
(50.71)\end{array}$ & 341,967 & $\begin{array}{c}51,803.88 \\
(83.64)\end{array}$ \\
\hline $\begin{array}{c}\text { San Francisco-Oakland- } \\
\text { Hayward, CA }\end{array}$ & $1,093,653$ & $\begin{array}{l}103,002 \\
(104.51) \\
\end{array}$ & 158,838 & $\begin{array}{c}57,390.85 \\
(149.73) \\
\end{array}$ & $1,000,088$ & $\begin{array}{c}75,509.03 \\
(81.11) \\
\end{array}$ \\
\hline $\begin{array}{c}\text { Washington-Arlington- } \\
\text { Alexandria, DC-VA }\end{array}$ & $1,744,508$ & $\begin{array}{c}83,386.65 \\
(48.41)\end{array}$ & 763,104 & $\begin{array}{c}59,174.61 \\
(51.72)\end{array}$ & 634,510 & $\begin{array}{c}64,730.37 \\
(70.35)\end{array}$ \\
\hline
\end{tabular}

Source: Author's calculations from the American Community Survey Data extracted from IPUMS for the year 2019. Standard errors of the means are provided in the parenthesis

For each metropolitan area, average pre-tax wages and salaries for white employed individuals exceeded that of the black employed workers. But the relative difference varied widely between the metropolitan areas. For example, in Atlanta-Sandy Springs- Roswell, GA, black employed individuals made about $67 \%$ of the average pre-tax wages and salaries compared to the white employed individuals to about $71 \%$ in WashingtonArlington-Alexandria, DC-VA, and 56\% in San Francisco-Oakland-Hayward, CA. In absolute terms, average pre-tax wages and salaries for white employed individuals was found to be highest in San Francisco-OaklandHayward, CA and lowest in Miami-Fort Lauderdale-West Palm Beach, FL. The same for black employed workers is highest in Washington-Arlington-Alexandria, DC-VA and lowest in Miami-Fort Lauderdale-West Palm Beach, FL. These differences possibly point to the occupational composition of the workers. For example, these results can be easily explained if the proportion of white workers in technologically advanced sectors more than black workers is compared to government jobs where the black workers may be represented at a relatively higher proportion compared to other occupations.

The income inequality of pre-tax wages and salaries by racial categories for different metropolitan areas are provided in Table 2. For every metropolitan area, income inequality among black workers is found to be smaller compared to white workers. In Table 1, black workers earned a smaller amount in terms of pre-tax wages and salaries, but their incomes were also less dispersed than their white counterparts. One may note that for every metropolitan area, income inequalities among other workers are also higher than the black workers. 
Furthermore, income inequality is higher among whites compared to other races in Atlanta-Sandy SpringsRoswell, GA, Los Angeles-Long Beach-Anaheim, CA, and San Francisco-Oakland-Hayward, CA, while the same is lower in all other metropolitan areas.

Table 2. Inequality (Gini Coefficient) of Pre-tax Wages and Salaries by Major Racial Categories for the Largest Metropolitan Areas

\begin{tabular}{|l|c|c|c|}
\hline \multicolumn{1}{|c|}{ Metropolitan Area } & White & Black & Others \\
\hline Atlanta-Sandy Springs-Roswell, GA & 0.478 & 0.391 & 0.465 \\
\hline Chicago-Naperville-Elgin, IL-IN-WI & 0.438 & 0.425 & 0.455 \\
\hline Dallas-Fort Worth-Arlington, TX & 0.438 & 0.396 & 0.447 \\
\hline Houston-The Woodlands-Sugar Land, TX & 0.454 & 0.409 & 0.464 \\
\hline Los Angeles-Long Beach-Anaheim, CA & 0.457 & 0.421 & 0.442 \\
\hline Miami-Fort Lauderdale-West Palm Beach, FL & 0.441 & 0.393 & 0.446 \\
\hline New York-Newark-Jersey City, NY-NJ-PA & 0.459 & 0.427 & 0.477 \\
\hline Philadelphia-Camden-Wilmington, PA-NJ-DE & 0.428 & 0.403 & 0.479 \\
\hline San Francisco-Oakland-Hayward, CA & 0.481 & 0.457 & 0.480 \\
\hline Washington-Arlington-Alexandria, DC-VA & 0.411 & 0.403 & 0.452 \\
\hline
\end{tabular}

Source: Author's calculations from the American Community Survey Data extracted from IPUMS for the year 2019

The ratio of income inequality between whites and blacks also differed between the metropolitan areas. For example, the ratio was 1.22 in Atlanta-Sandy Springs-Roswell, GA but 1.11 in Dallas-Fort Worth-Arlington, TX and 1.05 in San Francisco-Oakland-Hayward, CA. That ratio was found to the 1.12 for Miami-Fort Lauderdale-West Palm Beach, FL but 1.02 in Washington-Arlington-Alexandria, DC-VA. However, for Washington-Arlington-Alexandria, DC-VA, the ratio of inequality between other races and black workers stood at 1.21. In other words, while income inequalities were very comparable between whites and blacks, the same was relatively more acute for other races in Washington-Arlington-Alexandria, DC-VA. For Philadelphia-Camden-Wilmington, PA-NJ-DE metropolitan area, the ratio of income inequality was 1.06 between whites and blacks while the same was 1.89 between others and blacks. In other words, the relative income inequality between others and blacks was more pronounced compared to whites and blacks.

\section{Conclusions}

While racial disparities in income often make use of the differences in means across groups, this study contributes to the literature by providing the within and between-group income inequalities for major racial categories across the ten largest metropolitan areas of the USA. By doing so, this paper sheds light on the relative means for the major racial categories across geographically dispersed regions and the nature of that distribution for the same geographic and racial groups. It offers the readers a unique opportunity to compare the mean and the distribution of the pre-tax wages and salaries. For example, it is learned that black employees earned less in pre-tax wages and salaries than their white counterparts, but the distribution of the same was also much tighter among the blacks than the whites. While the uniformity of the pattern does raise significant concerns regarding the structurally discriminating nature of the American job market, the nature and presence of that discriminating pattern may not be established in any straightforward manner from these numbers, especially since no explicit control was accounted for. Such controls would include confounding variables like education, age, experience, the field of studies, nature of the occupation, etc. These factors must be kept in mind to avoid any over the interpretation of the results.

Funding. There is no funding for this research.

\section{References}

1. Acemoglu, D., \& Autor, D. (2011). Skills, tasks and technologies: Implications for employment and earnings. In Handbook of labor economics (Vol. 4, pp. 1043-1171). Elsevier. [Google Scholar]

2. Altonji, J.G., \& Blank, R.M. (1999). Race and gender in the labor market. Handbook of labor economics, 3, 3143-3259. [Google Scholar]

3. Angrist, J.D., \& Krueger, A.B. (1999). Empirical strategies in labor economics. In Handbook of labor economics (Vol. 3, pp. 1277-1366). Elsevier. [Google Scholar]

4. Arrow, K.J. (1998). What has economics to say about racial discrimination? Journal of economic perspectives, 12(2), 91-100. [Google Scholar] [CrossRef]

5. Autor, D.H., Katz, L.F., \& Kearney, M.S. (2008). Trends in US wage inequality: Revising the revisionists. The Review of economics and statistics, 90(2), 300-323. [Google Scholar] [CrossRef] 
6. Becker, G.S. (2010). The economics of discrimination. University of Chicago press. 178 p. [Google Scholar]

7. Bertrand, M., \& Mullainathan, S. (2004). Are Emily and Greg more employable than Lakisha and Jamal? A field experiment on labor market discrimination. American economic review, 94(4), 991-1013. [Google Scholar] [CrossRef]

8. Beyer, H., Rojas, P., \& Vergara, R. (1999). Trade liberalization and wage inequality. Journal of Development Economics, 59(1), 103-123. [Google Scholar]

9. Bisin, A., \& Gottardi, P. (2006). Efficient competitive equilibria with adverse selection. Journal of political Economy, 114(3), 485-516. [Google Scholar] [CrossRef]

10.Blau, F.D., \& Ferber, M.A. (1987). Discrimination: empirical evidence from the United States. The American Economic Review, 77(2), 316-320. [Google Scholar]

11.Blau, F.D., \& Kahn, L.M. (1996). International differences in male wage inequality: institutions versus market forces. Journal of political Economy, 104(4), 791-837. [Google Scholar] [CrossRef]

12.Boeri, T., \& Van Ours, J. (2013). The Economics of Imperfect Labor Markets: Princeton University Press.

13.Borjas, G.J. (1999). The economic analysis of immigration. Handbook of labor economics, 3, 1697-1760. [Google Scholar] [CrossRef]

14.Brown, R. (2011). Prejudice: Its social psychology: John Wiley \& Sons. 368 p. [Google Scholar]

15.Calvo-Armengol, A., \& Jackson, M.O. (2004). The effects of social networks on employment and inequality. American economic review, 94(3), 426-454. [Google Scholar] [CrossRef]

16.Card, D. (2001). The effect of unions on wage inequality in the US labor market. Industrial and Labor Relations Review, 54(2), 296-315. [Google Scholar] [CrossRef]

17.Chetty, R., Hendren, N., Jones, M.R., \& Porter, S.R. (2020). Race and economic opportunity in the United States: An intergenerational perspective. The Quarterly Journal of Economics, 135(2), 711-783. [Google Scholar] [CrossRef]

18.Collins-dodd, C., Gordon, I.M., \& Smart, C. (2004). Further Evidence on the Role of Gender in Financial Performance. Journal of Small Business Management, 42(4), 395-417. [Google Scholar] [CrossRef]

19.Croson, R., \& Gneezy, U. (2009). Gender Differences in Preferences. Journal of Economic literature, 47(2), 448-474. [Google Scholar] [CrossRef]

20.David, A., \& Dorn, D. (2013). The growth of low-skill service jobs and the polarization of the US labor market. American economic review, 103(5), 1553-1597. [Google Scholar] [CrossRef]

21.Delgado, R., \& Stefancic, J. (2017). Critical race theory: An introduction (Vol. 20): New York University Press. [Google Scholar]

22.Fortin, N., Lemieux, T., \& Firpo, S. (2011). Decomposition methods in economics. In Handbook of labor economics (Vol. 4, pp. 1-102): Elsevier. [Google Scholar] [CrossRef]

23.Fortin, N.M., \& Lemieux, T. (1997). Institutional changes and rising wage inequality: Is there a linkage? Journal of economic perspectives, 11(2), 75-96. [Google Scholar] [CrossRef]

24.Freeman, R.B., \& Katz, L.F. (1994). Rising wage inequality: the United States. Working under different rules, 29. [Google Scholar]

25.Glaeser, E.L., \& Resseger, M.G. (2010). The Complementarity Between Cities and Skills. Journal of Regional Science, 50(1), 221-244. [Google Scholar] [CrossRef]

26.Guerrieri, V., Shimer, R., \& Wright, R. (2010). Adverse selection in competitive search equilibrium. Econometrica, 78(6), 1823-1862. [Google Scholar] [CrossRef]

27.Hammond, T., \& Streeter, D.W. (1994). Overcoming barriers: Early African-American certified public accountants. Accounting, Organizations and Society, 19(3), 271-288. [Google Scholar] [CrossRef]

28.Harrison, G.W., \& List, J.A. (2004). Field experiments. Journal of Economic literature, 42(4), 1009-1055. [Google Scholar]

29.Heckman, J.J. (1998). Detecting discrimination. Journal of economic perspectives, 12(2), 101-116. [Google Scholar] [CrossRef]

30.Huang, G., Fowler, C.J., \& Baskerville, R.F. (2016). Entering the accounting profession: the operationalization of ethnicity-based discrimination. Accounting, Auditing \& Accountability Journal, 29(8), 1342-1366. [Google Scholar] [CrossRef]

31.Jones, C.I., \& Kim, J. (2018). A Schumpeterian model of top income inequality. Journal of political Economy, 126(5), 1785-1826. [Google Scholar] [CrossRef]

32.Juhn, C., Murphy, K.M., \& Pierce, B. (1993). Wage inequality and the rise in returns to skill. Journal of political Economy, 101(3), 410-442. [Google Scholar] [CrossRef]

33.Koeniger, W., Leonardi, M., \& Nunziata, L. (2007). Labor market institutions and wage inequality. Industrial and Labor Relations Review, 60(3), 340-356. [Google Scholar] [CrossRef] 
34.Krueger, A.O. (1963). The economics of discrimination. Journal of political Economy, 71(5), 481-486. [Google Scholar]

35.Lambert, P.J., \& Aronson, J.R. (1993). Inequality decomposition analysis and the Gini coefficient revisited. The Economic Journal, 103(420), 1221-1227. [Google Scholar] [CrossRef]

36.Lang, K., \& Lehmann, J.-Y. K. (2012). Racial discrimination in the labor market: Theory and empirics. Journal of Economic literature, 50(4), 959-1006. [Google Scholar] [CrossRef]

37.Lang, K., \& Manove, M. (2011). Education and labor market discrimination. American economic review, 101(4), 1467-1496. [Google Scholar]

38.Lemieux, T., MacLeod, W.B., \& Parent, D. (2009). Performance pay and wage inequality. The Quarterly Journal of Economics, 124(1), 1-49. [Google Scholar]

39.Levine, D.I. (1991). Just-cause employment policies in the presence of worker adverse selection. Journal of Labor Economics, 9(3), 294-305. [Google Scholar] [CrossRef]

40.Ma, C.-t. A. (1991). Adverse selection in dynamic moral hazard. The Quarterly Journal of Economics, 106(1), 255-275. [Google Scholar] [CrossRef]

41.Milanovic, B. (1997). A simple way to calculate the Gini coefficient, and some implications. Economics Letters, 56(1), 45-49. [Google Scholar] [CrossRef]

42.Moretti, E. (2012). The New Geography of Jobs: Houghton Mifflin Harcourt. [Google Scholar]

43.Moretti, E. (2013). Real wage inequality. American Economic Journal: Applied Economics, 5(1), 65-103. [Google Scholar]

44.Nance, J.P., \& Madsen, P.E. (2014). An Empirical Analysis of Diversity in the Legal Profession. Conn. L. Rev., 47, 271. [Google Scholar]

45.Neumark, D. (2018). Experimental research on labor market discrimination. Journal of Economic literature, 56(3), 799-866. [Google Scholar] [CrossRef]

46.Pager, D., \& Shepherd, H. (2008). The sociology of discrimination: Racial discrimination in employment, housing, credit, and consumer markets. Annual Review of Sociology, 34, 181-209. Available at: [Link]

47.Phelps, E.S. (1972). The statistical theory of racism and sexism. The American Economic Review, 62(4), 659-661. [Google Scholar]

48.Ray, A. (2021). Pre-Tax Wage and Salary Income Inequalities in Largest Metropolitan Areas in the United States. Business Ethics and Leadership, 5(2), 59-65. [Google Scholar] [CrossRef]

49.Rueda, D., \& Pontusson, J. (2000). Wage inequality and varieties of capitalism. World Politics, 52(3), 350-383. [Google Scholar] [CrossRef]

50.Song, J., Price, D.J., Guvenen, F., Bloom, N., \& Von Wachter, T. (2019). Firming up inequality. The Quarterly Journal of Economics, 134(1), 1-50. [Google Scholar] [CrossRef]

51.Yitzhaki, S. (1979). Relative deprivation and the Gini coefficient. The Quarterly Journal of Economics, 321-324. [Google Scholar] [CrossRef] 